(RESEARCH ARTICLE)

\title{
Mammals diversity in the Nutmeg Plantation area at Teluk Wondama and Teluk Bintuni Regency in West Papua Province, Indonesia
}

\author{
Anton S Sinery ${ }^{1,}{ }^{*}$, Hendrik Burwos ${ }^{1}$, Meliza Worabay ${ }^{1}$, Rina N, Jowey ${ }^{1}$ and Budi Setiawan ${ }^{2}$ \\ ${ }^{1}$ Environmental Research Center of Papua University, Indonesia. \\ ${ }^{2}$ School of PhD, Mulawarman University, Samarinda, Indonesia.
}

Publication history: Received on 05 January 2020; revised on 20 January 2020; accepted on 22 January 2020

Article DOI: https://doi.org/10.30574/wjarr.2020.5.1.0004

\begin{abstract}
This study aimed to determine the presence of mammals in the nutmeg plantation, at Teluk Wondama Regency and Teluk Bintuni Regency. The researchwas conducted from $1^{\text {st }}$ to $7^{\text {th }}$ August 2019 and the study area was located in Werianggi, Werabur and Idor villages. The total area of research was 8,000 ha and the area was considered as nonforest area (the area for other purposes) in the form of primary dryland forests, secondary dryland forests and shrubs that included lowland forest ecosystems, karts hills and swamp ecosystems. The result revealed that the areas containedhigh diversity of mammals, both family and species. The diversity of mammals found included marsupialia, Rodentia, and Chiroptera with total of 38 species.22 of species were belong toendemic species of Papua and 6 species were protected species according to Indonesian Emvironment and Forestry Ministry Regulation number P.106 / 2018 , and 5 species were included in the IUCN Red List category, and 2 species were listed in CITES Appendix II.
\end{abstract}

Keywords: Mammals; Diversity; Nutmeg plantation; Teluk Wondama; Teluk Bintuni

\section{Introduction}

Approximately 200 species of terrestrial mammals arefound in Papua and 154 of them have been formeda large populations that include endemic and introduced species[1] [2]. Itis estimated that Papua contains 20,000-25,000 species of woody plants; 164 species of mammals; 329 reptile and amphibian species; 650 species of birds; 250 freshwater fish species; 150,000 species of insects which are endemic and protected [3]. Moreover, it has been recently recorded that Papua has 191 species of native mammals include 40 endemic species.

Ecologically, the existence of wild animals in ecosystems isinfluenced by various environmental components (external). Therefore, the ability of individuals internally, related to species, population, trait and habitatabsolutely has to be understood in wildlife management [4]. According to [5], the dynamic of wildlife population depends not only on the rate of birth (natality) and death (mortality), but also the ability of animals to enter (immigrate) or exit (emigrate) in and outofpopulation. According to [6], the range of species is able to change due to to climate change and landscapestructures, as well as the ability of reproduction and adaptation ofoffsprings. The quality and quantity of habitat are therefore determining the prospect for the use and sustainability of wildlife.

The presence of the potential mammalsiscurrently faced with threats caused by habitat loss and hunting activities. Therefore, various efforts continue to be carried out by the national government, regional government and various parties.One of the effortsisto recognize the optimization of protected areas based on the strategic environmental assessment of West Papua marine (KLHS RZWP3K =39\%) and regional spatial planning (KLHS RTRW = 55-60\%) which includeterrestrial conservation, mangrove, swamp, peat, local protection, disaster prone, geological protection, spiritual culture and HCV and other areas.

\footnotetext{
${ }^{*}$ Corresponding author

E-mail address: anton_sineri@yahoo.com
} 
The purposeof the research was to determine the species of mammals in the area of nutmeg plantation at Nikiwar District of Teluk Wondama Regency and Idoor Village of Teluk Bintuni Regency.

\section{Materials andmethods}

\subsection{Time and Location}

The research was conducted for 2 months (from August to September 2019) and located in the area of the planned 8,000 ha in Werianggi, Werabur and Idor villages. The area isconsidered as the area for other purposes ( non-forest area/APL) which includes primary dryland forest, secondary dryland forest and shrubs consisting of lowland forest ecosystems, karts hills and swamp ecosystems.

\subsection{Data Collection and Analysis}

Data ofspecies and individuals of mammal groups werecollected through the survey in the field, accompanied by direct capture, cage traps,mist nets and interview. The survey was carried outin the area of nutmeg plantations, particularly in the mid-nursery locations of Werabur and Werianggi villages, lowland forests around Idoor village and karts area around Maskeri Mount and area around sago hamlets. Direct observation was done by tracing transects at each observation location both during the day and the night.

Small non-volant mammals such as groups of mice andsquirrels were caught using conventional traps (cage trap units), while for groups of volant mammals such as bats (including birds) were caught using miss net as well as 2 camera traps for each location. Furthermore, interviewwas also conducted with the community related tospecies and their distribution to provide information the other types of mammals that were not directly observed. The interview was specifically referred to 3 community leaders and representatives of 12 communities in the three villages in the study area. These respondents were those who acknowledgedand were directly related to wildlife management (utilization). Research data consisting of species, individuals and their distribution were descriptively analyzed and displayed in tables and figures.

\section{Results and discussions}

\subsection{Species of Mammals}

The study'sresult showed that the nutmeg plantation area had high diversity of mammals. This was indicated by 38 species of mammals found in the study sites., which consisted of 16 species of marsupial group, 15 species of Chiroptera, and 7 species of Rodentia. Compared with previous mammalian records in other several sites, these number of species were considered bigger than the species found in the other sites. For example, in the POD I Genting Oil Kasuri area in Sumuri District, Teluk Bintuni Regency, it wasidentified 27 species of mammals in this area [3]. Likewise, in the Gunung Meja natural tourism park, it was reported as many as 15 species of mammals were found in the forest, [7]or also in the Sorong natural tourism park, it was reported as many as 14 species found in the area.[8]. Thisindicates that the study areahas a fairly good habitat carrying capacity and is a characteristic of lowland forests that isrich in various animal needs. According to [9][10] [11][12] Numfor island forest, Ahe Island forest, Gunung Meja forest, Arfak mountains, and generally lowland forest are considered as the good habitats for animals because they provide various vegetations for animals' foods., including vegetationsfor wildlifes.

The species of mammalsrecorded in study area(forest area around Werabur villageswhere the nutmeg nursery was located, Maskeri Mount, swamp forest and lowland forest around Idor villages, at Teluk Bintuni Regency) is shown in the table 1. 
Table 1 Species of Mammals in the Nutmeg Plantation Area at Teluk Wondama and Teluk Bintuni Regencies

\begin{tabular}{|c|c|c|c|c|c|c|c|c|c|c|}
\hline \multirow[t]{2}{*}{ No } & \multirow[t]{2}{*}{ Ordo/Famili } & \multirow[t]{2}{*}{ Species } & \multicolumn{4}{|c|}{ Location } & \multirow{2}{*}{$\begin{array}{l}\text { Ende } \\
\text { mik }\end{array}$} & \multirow{2}{*}{$\begin{array}{l}\text { IUC } \\
\mathbf{N}\end{array}$} & \multirow{2}{*}{$\begin{array}{l}\text { CITE } \\
S\end{array}$} & \multirow{2}{*}{$\begin{array}{l}\text { P.10 } \\
6 / \\
2018\end{array}$} \\
\hline & & & 1 & 2 & 3 & 4 & & & & \\
\hline & Marsupialia & & & & & & & & & \\
\hline 1 & Dasyuridae & Antechinus nosa (Jentink, 1911b) & & $\sqrt{ }$ & $\sqrt{ }$ & $\sqrt{ }$ & $\mathrm{N}$ & $\mathrm{LC}$ & & \\
\hline 2 & Dasyuridae & $\begin{array}{l}\text { Dasyurus albopunctatus } \quad \text { (Schlegel, } \\
1880 \text { ) }\end{array}$ & & & $\sqrt{ }$ & & $\mathrm{N}$ & NT & & \\
\hline 3 & Peroryctidae & Echymipera kalubu (Lesson,1828) & $\sqrt{ }$ & $\sqrt{ }$ & $\sqrt{ }$ & $\sqrt{ }$ & $\mathrm{N}$ & LC & & \\
\hline 4 & Peroryctidae & E. rufescens (Peters \& Doria 1875) & & $\sqrt{ }$ & $\sqrt{ }$ & $\sqrt{ }$ & $\mathrm{N}$ & $\mathrm{LC}$ & & \\
\hline 5 & Macropodidae & Dorcopsis muelleri (Schlegel, 1866b) & $\sqrt{ }$ & $\sqrt{ }$ & $\sqrt{ }$ & $\sqrt{ }$ & $\mathrm{N}$ & $\mathrm{LC}$ & & \\
\hline 6 & Macropodidae & Dendrolagus inustus (Muller,1840) & & & $\sqrt{ }$ & & $\mathrm{N}$ & VU & II & $\mathrm{L}$ \\
\hline 7 & Macropodidae & Dendrolagus ursinus (Muller,1840) & & & $\sqrt{ }$ & & $\mathrm{N}$ & VU & II & $\mathrm{L}$ \\
\hline 8 & Phalangeridae & $\begin{array}{ll}\text { Spilocuscus } & \text { maculatus } \\
\text { (Desmarest,1818) } & \end{array}$ & & $\sqrt{ }$ & $\sqrt{ }$ & $\sqrt{ }$ & N.M & $\mathrm{LC}$ & & $\mathrm{L}$ \\
\hline 9 & Phalangeridae & Spilocuscus rufoniger (Zimara, 1937) & & $\sqrt{ }$ & $\sqrt{ }$ & $\sqrt{ }$ & $\mathrm{N}$ & $\mathrm{CR}$ & & $\mathrm{L}$ \\
\hline 10 & Phalangeridae & Phalanger orientalis (Pallas, 1766) & $\sqrt{ }$ & $\sqrt{ }$ & $\sqrt{ }$ & $\sqrt{ }$ & N.M & LC & & \\
\hline 11 & Acrobatidae & Distoechurus pennatus (Peters,1874) & $\sqrt{ }$ & $\sqrt{ }$ & $\sqrt{ }$ & $\sqrt{ }$ & $\mathrm{N}$ & LC & & \\
\hline 12 & Petauridae & Petaurus breviceps (Waterhouse,1838) & $\sqrt{ }$ & $\sqrt{ }$ & $\sqrt{ }$ & $\sqrt{ }$ & $\mathrm{N}$ & $\mathrm{LC}$ & & \\
\hline 13 & Petauridae & $\begin{array}{l}\text { Dactylopsila palpator (Milne Edwards, } \\
\text { 1888) }\end{array}$ & & $\sqrt{ }$ & $\sqrt{ }$ & & $\mathrm{N}$ & $\mathrm{LC}$ & & \\
\hline 14 & Petauridae & Dactylopsila trivirgata (Gray 1858a) & $\sqrt{ }$ & $\sqrt{ }$ & $\sqrt{ }$ & $\sqrt{ }$ & $\mathrm{N}$ & LC & & \\
\hline 15 & Suidae & Sus scrofa & $\sqrt{ }$ & $\sqrt{ }$ & $\sqrt{ }$ & $\sqrt{ }$ & A & $\mathrm{LC}$ & & \\
\hline \multirow[t]{2}{*}{16} & Cervidae & Rusa timorensis & $\sqrt{ }$ & $\sqrt{ }$ & $\sqrt{ }$ & $\sqrt{ }$ & A & VU & & \\
\hline & Chiroptera & & & & & & & & & \\
\hline 17 & Pteropodidae & Pteropus neohibernicus (Peters,1876) & $\sqrt{ }$ & $\sqrt{ }$ & $\sqrt{ }$ & $\sqrt{ }$ & A & VU & & $\mathrm{L}$ \\
\hline 18 & Pteropodidae & Dobsonia magna (Thomas, 1905a) & $\sqrt{ }$ & $\sqrt{ }$ & $\sqrt{ }$ & $\sqrt{ }$ & N.M & $\mathrm{LC}$ & & \\
\hline 19 & Pteropodidae & Dobsonia minor (Dobson,1879) & $\sqrt{ }$ & $\sqrt{ }$ & $\sqrt{ }$ & $\sqrt{ }$ & $\mathrm{N}$ & $\mathrm{LC}$ & & \\
\hline 20 & Pteropodidae & Macroglossus minimus (Geoffroy,1810) & $\sqrt{ }$ & $\sqrt{ }$ & $\sqrt{ }$ & $\sqrt{ }$ & $\mathrm{N}$ & $\mathrm{LC}$ & & \\
\hline 21 & Pteropodidae & Syconycteris australis (Peters,1867) & $\sqrt{ }$ & $\sqrt{ }$ & $\sqrt{ }$ & $\sqrt{ }$ & N.A & LC & & \\
\hline 22 & Pteropodidae & Nyctimene aello (Thomas,1900a) & $\sqrt{ }$ & $\sqrt{ }$ & $\sqrt{ }$ & $\sqrt{ }$ & $\mathrm{N}$ & $\mathrm{LC}$ & & \\
\hline 23 & Pteropodidae & Paranyctimene raptor & $\sqrt{ }$ & $\sqrt{ }$ & $\sqrt{ }$ & $\sqrt{ }$ & $\mathrm{N}$ & $\mathrm{LC}$ & & \\
\hline 24 & Pteropodidae & Nyctimene albiventer (Gray, 1863) & $\sqrt{ }$ & $\sqrt{ }$ & $\sqrt{ }$ & $\sqrt{ }$ & N.M & $\mathrm{LC}$ & & \\
\hline 25 & Pteropodidae & $\begin{array}{l}\text { Rousettus } \quad \text { amplexicaudatus } \\
\text { (Geoffroy,1810) }\end{array}$ & $\sqrt{ }$ & $\sqrt{ }$ & $\sqrt{ }$ & $\sqrt{ }$ & $\mathrm{A}$ & $\mathrm{LC}$ & & \\
\hline 26 & Hipposideridae & $\begin{array}{l}\text { Hipposideros papua (Thomas \& Doria, } \\
\text { 1886) }\end{array}$ & $\sqrt{ }$ & $\sqrt{ }$ & $\sqrt{ }$ & $\sqrt{ }$ & $\mathrm{N}$ & $\mathrm{LC}$ & & \\
\hline 27 & Hipposideridae & Hipposideros diadema (Geoffroy,1813) & $\sqrt{ }$ & $\sqrt{ }$ & $\sqrt{ }$ & $\sqrt{ }$ & A & $\mathrm{LC}$ & & \\
\hline 28 & Hipposideridae & $\begin{array}{l}\text { Hipposideros maggietaylorae (Smith \& } \\
\text { Hill,1886) }\end{array}$ & $\sqrt{ }$ & $\sqrt{ }$ & $\sqrt{ }$ & $\sqrt{ }$ & I & $\mathrm{LC}$ & & \\
\hline
\end{tabular}


Anton et al. / World Journal of Advanced Research and Reviews, 2020, 05(01), 079-085

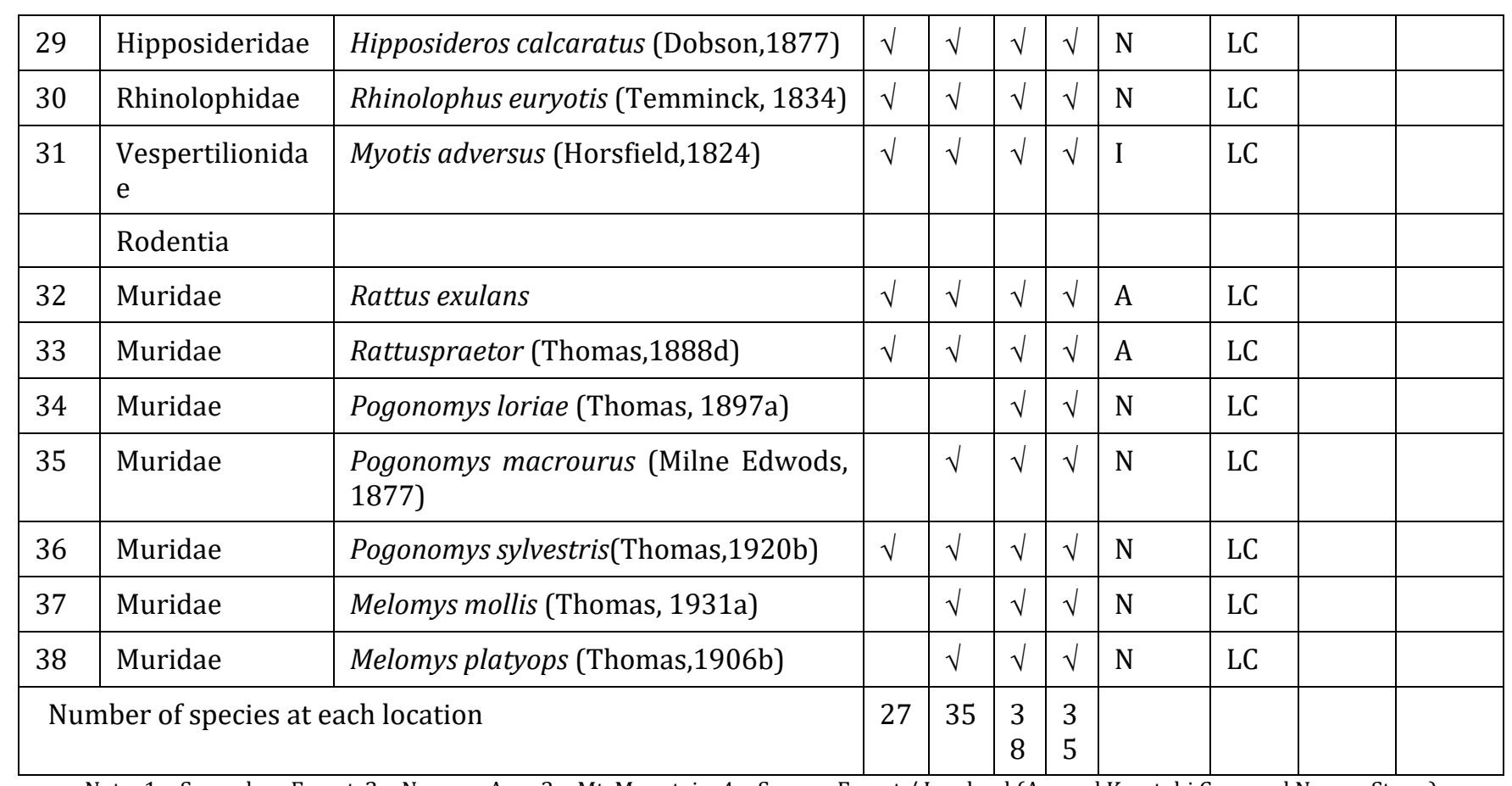

Note: 1 = Secondary Forest, 2 = Nursery Area,3 = Mt. Mountain, 4 = Swamp Forest / Lowland (Around Karatobi Cave and Nassey Stone) $\mathrm{N}=$ New Guinea, $\mathrm{M}=$ Molucas $\mathrm{A}=$ Australia, $\mathrm{I}=$ Indonesia

\section{Description of species}

Observation indicated the numberof species as illustrated through the individual distribution found in four study sites was different. In Werabur village, 23 species of mammals were identified and in nutmeg nursery, 34 species were found. While in 2 other sites, Mt Maskeri and ,Idor village, the number of mammals species found was 37 species and 34 species respectively. Several smilar species were found in four locations, however, some of other species were just only found in one location. Refering to the number of species found, Mt Maskeri, Idor Village and nutmeg nursery were considered indeed rich compare to Werabur village. This explainsthe difference in habitat quality which determines the concentration of animal population.

Most families of mammals found were belong to Marsupialorder with the total number of family was8, thus it was followed by Chiroptera order with 4 families and Rodent order with only 1 Family.Based on the observation, 38 species of mammals were dividedinto 13 families with the highest number of species were Petropodidae (9 species), thus followed by the Hipposideridae and Petauridae which had 4 species respectively, Phalangeridae and Macropodidae with 3 species respectively. Furthermore, the other six families justhad one species in their groups. The collected data was cumulative result of identification of mammal species in 4 observation siteswhich was a fairly wide area. In addition, different coverage of the sampling area,time of the survey, microclimate conditions (such as rainy days, temperature and humidity) as well asspecies behaviorswould greatly affect the observationof mammals in this research.

According to observations, interviews and literature studies, it was assumed that more than 16 species of marsupials were found in this forest area, however, in this research six types of marsupial mammals were identified. Three types of them were protected according to regulation of Indonesian Environment and Forestry Ministry number P.106 in 2018 as well as registered in IUCN and CITES (Table 1).

Cenderawasih tree kangaroo (Dendrolagus ursinus) is endemic species of birdheads and it can be found in the Arfak Mountains and the Fakfak Peninsula. According to [13], this species could be found from 0 to $2300 \mathrm{~m}$ asl ofprimary forest. According to local community, this species was found by the community around MtMaskeri a few days before the research activity is running. Cenderawasih tree kangaroos (Dendrolagus ursinus)reproduce throughout the year and breastfeed child for 5-6 months. The species has a physiological characteristic called embryo diapause or delayed birth. This allowsthe females to remarry immediately after giving birth or when they still have baby in the baby bag. However, the development of the fertilized egg ispostponed until the child almost ends the life in the bag. The absence of the child in the bag triggers further development until the next birth. Unlike the Porcupine papua (Ekidna), the social nature and the desireof collecting this species is one of factors causesthis type of population declining. Successful kangaroo hunting 
not only could kill an animal, but alson all members of the family group. [2]. Cenderawasih tree kangaroo isincluded in the IUCN Vulnerable Red list category with a declining population in nature, besides P.106 / 2018.

Ordinary wallaby (Dorcopsis muelleri) or land kangaroowas documented to occupy the western lowlands of mainland Papua and Misool, Salawati, and Yapen islands[2] [13]. The spread of this animalisvery wide and the animal iseasilyfound near human settlements. Wide eyes aretypical eyes of nocturnal animals, however, this animal could be active during part of the day when there issunlight. This species had a very large population in this area, but only footprints were found during field observation. According to local community, for hunting wallabies, they must walk quite far from the village or the main road. This occurs since population of the animal is declining due to overhunting and habitat disturbance. Eventhough population of wallabyisabundant in nature, this animal in several areas faces a serious threat due to overhunting for local consumption. Moreover, the loss of habitat due to the conversion of forests to agricultural lands and community gardens has impacted number of the population in nature.

The spotted cuscus (Spilocuscus maculatus) is greatlydemand by the public due to the unique shape and the beautiful color of hair. In addition, the meat of this animal is good for consumption and the skin could be used as an attractive decorationin the house. This species is very common in areas and could be found at an altitude of 0 to $1200 \mathrm{~m}$ asl in primary and secondary forests throughout Papua, except savanna areas. [13]. The black spotted cuscus (Spilocuscus rufoniger) has a striking color that distinguishes it from the other two types in the genus Spilocuscus. Males ussually has a color pattern depicted as placement of reddish brown on a white background and black on a brown background. Female hair isbrighter and dominated by white to yellow flesh. East cuscus (Phalanger orientalis) isone ofcuscus species that has nospott . Similar to Spilocuscus maculatus, this species isdesirable for consumption. East cuscus(Phalanger orientalis) islively scattered in Papua, but it has not been reported for Southern Papua. The species spreads from 0 to $1500 \mathrm{~m}$ asl, and it could be found in primary forests, secondary forests, as well as the former garden. This species isalso discoveredin the islands around Teluk Wondama region such as Roon and several other islands. In 2017 and 2018, 1 and 2 individuals of this species respectively were discovered by the people in Wasior region.. According to [4], east cuscus (Phalanger orientalis) is more adaptive to habitat changes so that it could be found in secondary forests and community gardens instead of primary forests. The ground couscus (Phalanger gymnothis) isthe second largest cuscus after Spilocuscus maculatus and weight of the male could reach $5 \mathrm{~kg}$. The term "ground cuscus" is confirmed asthis species lives in holeofthe ground, blemish rock or under the rubble of rock. The ground couscus (Phalanger gymnothis) is also well-known as a large dental cuscus which is synonym for large late premolar teeth, an indicator in identification through the anatomy of this species. It has brown fur color similar to wool, sometimes it could be seen silvery effect, dorsal brown or gray and ventral rather white. The color of the black tail isusuallyaccompanied by white at the tip of the tail.The lower surface of the species tail resembles a grated wood (sand paper), ending more conspicuously and tapering to the tail tip regularly like the tail of Phalanger orientalis[2] [13]. These three species of cuscus were found in this area. These three species areprotected in accordance with P.106 / 2018 and CITES Appendix II.

Dactylopsila palpatorisa type of possumswhichis widespread in several locations such as the bird's head region, central New Guinea and the huon peninsula. The species is assumed to have large population in nature, however,the number of population of this species hasnot been yet recorded. Occasionally, the animalishunted by local people for consumption and decoration. Based on the interview, the meat of the species provided the need of daily consumption and the skin of the species was usedfor decoration.Eventhough the species is hunted by local people, interestingly, hunting of this species isnot considered as a significnat threatsince it is difficult to find the species in forest.

The rodentia group recorded wasintroduced mice (not native to New Guinea), endemic mice of the genus Rattus, slippery-tailed mice, and the oldest endemic mice from Papua [13]. Three species of mice were identified as Papuan endemic mice. Local communities in severalareas not often consume miceas the main protein, as a consequencethe population of native Papuan miceis suggestedto quite available in nature. Nevertheless, compared with the introduced mice which isvery adaptive to the environment and has high reproduction rate, most of native Papuan mice are solitary animals and have a low reproduction rate. The three native species of mice collected in the area representedthe diversity of endemic mamals species of the area.It was indicated thatthere were four other species of mice instead of the three species that actually could be found in the location. One of them was Stenomys verecundus (New Guinea endemic). Stenomys verecundus is commonlyfound in a variety of habitats which is from primary tropical rain forests to remote gardens. The population of this species is huge in nature and there isno significant threat to this species [14] [15].

Chiroptera consists of two groups namely Megabat (plant eater) and Microbat (insect eater). Bats havesomeimportant roles such asspreading seeds in the forest, facilitatingthe process of pollinatition of some plants, controlling insect pests, and producing guano fertilizer. It was estimated that around 15 species of Megabats and Microbats existed in the study sites, however, only 7 species could be found in the areas. The total number of species of bats was largery found in Werabur village instead of Idoor village. Three species were found in the forests around the Werabur village and nutmeg 
nursery, but no one species was found in the Mt. Maskeri forest. Several bats use cave as a permanent place to live, such as Dobsonia magna, Hipposideros maggietaylorae, H. calcaratus, Rhinolophus euryotis, Myotis moluccarum, and Nyctophilus microtis. These bats could notbe separated from the cave, therefore if there is damage to the cave, it would threaten these animals. In contrast, thebats that use the cave only for certain purposes, they could still find another place to live such as forest vegetation. The other bats thatmight existin this area were belong to large fruit-eating groups (Flying foxes), especially Pteropus neohibernicus. Pteropus neohibernicushaslarge body size and wide wings, which make the range of cruising of the speciescould reach tens of kilometers. This species usually rests during the day by hanging on in the branches of tall trees as well as certain species of trees, butin the night, this species flies over trees canopies which makes the species is difficult to catch. The only way to hunt this species is by using rifles to shoot the animal. Local people hunt and consume Pteropus neohibernicusbecause it hasbig body size and the people belief that the liver of the bat could cure asthma. Pteropus neohibernicusis one of bats speciesthat has abundant population in nature, however, the biggest threat of this type even all the genus Pteropus is overhunting by humans for daily consumption. According to Salas et al (2008), the decline in P. neohibernicus population occurred in the Gazelle Peninsula, East New Britain; Western East Sepik; New Britain; and Manus Island (Papua New Guinea). The serious threat to the bat population particularly the genus Pteropus in several regions in PNG had resultedall these genera to include in the CITES appendix II category. The Indonesian government had also adopted the policy for the protection of all Pteropus genera based on P.106 /2018.

\section{Conclusion}

The area of the nutmeg plantation contained high diversity of mammals' species, both families and species. Thirty eight species of Marsupialia, Rodentia, and Chiroptera were identified in the area of study in which 22 species were classified as endemic species, 6 species were considered as protected species according to P.106 / 2018, 5 species were included in the IUCN Red List category, and 2 species were listed in Appendix II CITES.

\section{Compliance with ethical standards}

\section{Acknowledgments}

The authors wishes local community in Wasai Village, Arfai I Village and Environmental Research Centar of Papua University assisted during field data collection. Special thanks is also extended to those who contributed to the research and writing of this article.

\section{Disclosure of conflict of interest}

The authors declare no conflicts of interest regarding the publication of this paper.

\section{References}

[1] Petocz RG. (1987). Konservasi Alam dan Pembangunan di Irian Jaya. Jakarta: Pustaka Grafitipers.

[2] Petocz RG. (1994) Terrestrial Mamalia of Irian Jaya. PT Gramedia Pustaka Utama, Jakarta. [Indonesian].

[3] Krey K, Warmetan H, Mamboai H, Parenden D, Lekitoo K, Tukayo R, Ronsumbre A, Hematang F, Koromari B, Tambing Y, Dubri Y and Sinery A. (2019). Kasuri Block High Conservation Value. Deepublish, Yogyakarta.

[4] Sinery AS. (2015). Management Strategies of Cuscus on the Numfor Island. Deepublish, Yogyakarta. [Indonesian].

[5] Odum P. (1993). Fundamentals of Ecology. 3rd ed. Gajah Mada Univ. Press, Yogyakarta [Indonesian].

[6] Primack, Supriatna and Indrawan dan Kramadibrat. (2000). Conservation Biology. Yayasan Obor Indonesia.

[7] Manusawai J and Leonard D. (2015). Potential and Managemen Strategis of Gunung Meja Tourism Park. Deeppublish, Yogyakarta. [Indonesian]

[8] FonatabaY, Aipassa MI, Simarangkir, B.D.A.S, Sumaryono, Jacob M, Vera FM and Anton SS. (2018). Community Participation in the Management of Sorong Nature Tourism Park, Sorong City. Journal of Energy and Environment Research, 8 (1), 48-55.

[9] Sinery AS, Farida WR and Manusawai J. (2016). The population of spotted cuscus (Spilocuscus maculatus) and its habitat carrying capacity in Numfor Island, Papua, Indonesia. Biodiversitas, 17(1), 315-321. 
[10] Sinery AS, Boer C and Farida WR. (2013). Population dynamics of cuscus in tourist island of Ahe, District of Nabire, Papua. Biodiversitas, 14 (2), 95-100.

[11] Sinery AS. (2006). Species of Cuscus in Taman Wisata Gunung Meja Manokwari Regency, West Irian Jaya. Biodiversitas, 7 (2), 175-180.

[12] Population dynamics of cuscus in tourist island of Ahe, District of Nabire, Papua. Biodiversitas, 14 (2), $95-100$.

[13] Flannery T. (1995).Possums of the World.A Monograph of the Phalangeroidea. Geo Production Pty Ltd, Australia.

[14] Leary T, Sery,L, Wright D, Hamilton S, Helgen K, Singadan R, Menzies J, Allison A, James R, Dickan C, Alpin K, Flannery T, Martin R and Salas L. (2016). Dendrolagus Inustus. Red list dangerous species IUCN, e.T6431A21957669.

[15] Leary T, Singadan R, Menzies Helgen KJ, Allison A, James R, Flannery T, Alpin K. DickanC and Salas L. (2016). Spilicuscus rufoniger. Red list dangerous species IUCN 2016 IUCN, e.T6431A21957669.

[16] IUCN Red List of Threatened Species, Version 2010.

\section{How to cite this article}

Anton SS, Hendrik B, Meliza W, Rina NJ and Budi S. (2020). Mammals diversity in the Nutmeg Plantation area at Teluk Wondama and Teluk Bintuni Regency West Papua Province, Indonesia. World Journal of Advanced Research and Reviews, 5(1), 79-85. 